\title{
STAKEHOLDERS IN THE ADVENTURE TOURISM DEVELOPMENT AT CURUG BIBIJILAN SUKABUMI REGENCY
}

\author{
Eva RACHMAWATI ${ }^{*}$ AND MUHAMAD REDITO GEA ANJANA \\ Department of Forest Conservation Resources and Ecotourisme, Faculty of Forestry and Environment Institut \\ Pertanian Bogor, Bogor, 16680, Indonesia \\ *Email: eva.rachmawatisolihin@gmail.com
}

Accepted July 13, 2021 / Approved September 01, 2021

\begin{abstract}
Bibijlan waterfall is a destination that has the potential to be developed as an adventure tourism area. The development of tourism cannot be separated from the role of stakeholders. This study analyzes the current and potential stakeholders involved in developing adventure tourism in Curug Bibijilan and examines the expected involvement based on stakeholder analysis. The research was carried out using interviews, field observations, and literature studies. The analysis was carried out quantitatively and qualitatively. Stakeholder analysis is carried out to identify stakeholders, classify and map stakeholders, and analyze relationships between stakeholders. The results showed that ten identified stakeholders have been involved and have not been involved in developing adventure tourism in Curug Bibijilan. The stakeholders in the key player's (strong influence and high importance) group were Perhutani, Kompepar, and BAT. The stakeholders in the contex setter (Quadrants III - strong influence but low interest) was Kertaangsana Village. There were no identified stakeholders in quadrants II as the subject of the natural tourism development of Curug Bibijalan. Stakeholders identified in quadrant IV (crowds - low influence and low interest) include LMDH, the Tourism Office, the Transportation Service, the Water Service, and the Energy and Mineral Resources Office. There were three relationships between each identified stakeholder, namely communication, cooperation, and coordination.
\end{abstract}

Key words: coordination, communication, natural tourism, stakeholder mapping

\section{INTRODUCTION}

Sukabumi Regency is included in the special interest tourism area in the southern part of West Java. This area is one of nine areas with priority tourism destination in West Java Province, contained in the West Java Regional Tourism Development Master Plan (RIPPDA) (Tarigan et al., 2018). Tourism potential is a variety of resources owned by a place and can be developed into a tourist attraction used for economic purposes while still paying attention to other aspects (Pendit, 2006). One type of tourism currently experiencing rapid development and has a large market is adventure tourism (Weber, 2001; Rantala and Rokenes, 2016; Cheng et al., 2018).

Adventure tourism can be defined as guided commercial tourism, where the main attraction is outdoor activities that rely on natural terrain features and generally require special equipment (Buckley, 2006). Cheng et al. (2018) have identified three focus areas in adventure tourism development, including adventure tourism operators, enhancing adventure tourism experiences, and destination planning and development. To realize it all, the management and development of adventure tourism destinations in an area cannot be done only by the area manager. However, it will require support and contributions from various tourism stakeholders (Kurniawan et al., 2016; Fairuza, 2017; Hanafiah et al., 2016).

Stakeholders are individuals or groups who have an interest, influence (positive or negative), and are involved in a development program (Mahfud et al., 2015). Stakeholders can come from government agencies, the private sector, and the community. Each stakeholder has a different important role and needs to be understood in developing tourist objects and attractions in an area (Amalyah et al., 2016). Often, effective stakeholder engagement is presented as a prerequisite for effective and sustainable tourism planning. The fragmented nature of the industry is suggested as a critical need for cooperation, as many different stakeholders have an interest in the tourism planning process (Minnaert, 2020). Only through information sharing and decision-making with all the stakeholders involved can tourism planning develop with minimal negative impacts (Ladkin and Bertramini, 2002). One example of a case related to the role of stakeholders in tourism development is the results of Santoso et al., (2015) research in Bunaken National Park, North Sulawesi which shows that synergy between stakeholders becomes important in tourism development. According to Santoso et al., (2015), the stakeholders in the development of natural tourism in conservation areas present a conception of tourism development that cannot be done alone and demands together direction of action and balance of stakeholders.

One of the tourism objects that can be developed as an adventure tourism destination is the Curug Bibijilan area, Sukabumi Regency. The area has several natural potentials that could be used to do adventure activities. The development of the natural tourism area of Curug 
Bibijilan has not run optimally due to limited human resources as tourism managers (Area manager, 18 March 2021, Personal communication). This is a concern for current stakeholders, especially tourism development, which is expected to be directed at the type of adventure tourism in the future. Efforts to realize tourism development in dealing with the above problems need support, coordination, cooperation, and commitment from other stakeholders who are currently not developing natural tourism in Curug Bibijalan. Therefore, examining each stakeholder role can be identified based on their level of interest and influence in developing natural tourism at Curug Bibijilan.

\section{RESEARCH METHOD}

The research was conducted in March-April 2021 in the natural tourism area of Curug Bibijilan, Sukabumi Regency. The tools used in this research are cameras for documentation purposes, voice recording devices, and laptops equipped with Microsoft Word and Microsoft Excel application software. The instruments used are interview guides and stakeholder influence and interest assessment sheets. The types of data collected in this study are primary data and supporting data. The primary data were obtained from field results through interview guides to stakeholders involved in tourism development, while potential stakeholders were identified through interviews and literature studies. Supporting data obtained from the literature study. The primary data collected from interviews are the stakeholders involved, the role of stakeholders, and the interests and influences of stakeholders in tourism development, while the supporting data collected includes the general condition of the research location.

The research data were taken through interviews, field observations, and literature studies. An interview is a data collection technique to obtain data or information from informants (Idrus, 2009). This study uses semistructured interviews based on interview guides prepared previously and conducted face-to-face with stakeholders. Semi-structured interviews are interviews with informants guided by researchers related to research topics that have been compiled in the interview guide (Widodo, 2017). The sampling technique uses snowball sampling. The first informant is the Curug Bibijilan area manager who assumed is understands and has knowledge of the research topic. The first informant in the study was Perum Perhutani Forest Management Resort (RPH) Ciguha Forest Management Unit Section (BKPH) Cikawung Forest Management Unit (KPH) Sukabumi. Further information is obtained from the recommendations of the first informant (Widodo, 2017). Informants interviewed included Perum Perhutani Forest Management Resort (RPH) Ciguha Forest Management Unit Section (BKPH) Cikawung Forest Management Unit (KPH) Sukabumi, Kertaangsana Village Government, and Tourism Care Community Group
(Kompepar). Field observations are made to identify the general biophysical conditions of the research site including the flora and fauna in the area. The literature study was carried out by looking for various types of relevant research related to the research carried out and to obtain initial information on tourism development. Some of the literature studies studied include journals, theses, tourist visit reports, and tourism development plan documents.

Stakeholder analysis includes three stages: identifying stakeholders, classifying and mapping stakeholders, and analyzing relationships between stakeholders (Reed et al., 2009). Data analysis was carried out by using quantitative and qualitative descriptive methods. The quantitative descriptive method is the process of consciously understanding the problems in an area and describing the problem factually and accurately under the conditions sought (Trihayuningtyas et al., 2018). This analysis is used to assess the influence and interests of stakeholders quantitatively. The qualitative descriptive method describes the involvement of potential stakeholders in the development of adventure tourism at Curug Bibijilan based on the results of the latest stakeholder analysis. Analysis of the role of stakeholders in the development of natural tourism Curug Bibijilan using the analysis model of Reed et al. (2009). The following stages of stakeholder analysis are explained as follows:

\section{Stakeholders identification}

Stakeholder identification was carried out to identify the stakeholders involved in developing naturebased tourism in Curug Bibijilan. Identification of stakeholders and their interests is done by airy observations and interviews with snowball sampling. Stakeholder identification is carried out by verifying stakeholders involved in tourism development by information about stakeholders from the first informant source. Stakeholders selected with the consideration concerned have experience and knowledge in accordance with the focus of research. Furthermore, based on data and information obtained from previous stakeholders, researchers can determine other stakeholders who are considered to provide more complete data. Then a literature study is carried out.

\section{Stakeholder mapping}

Stakeholders are mapped into a stakeholder analysis matrix based on the magnitude of the interests and influence of stakeholders in tourism development. The measurement of the level of interest and influence of stakeholders is based on five main questions that have been prepared previously. The level of importance is assessed based on the involvement of stakeholders in tourism development (K1), the benefits of tourism development for stakeholders (K2), the authority of stakeholders in tourism development (K3), the priority scale of stakeholders in tourism development (K4), and the level of stakeholder dependence on tourism development (K5). The magnitude of the level of 
influence is assessed based on the role of stakeholders in tourism development, the authority of stakeholders in interactions related to tourism development, supervision and evaluation of stakeholders in tourism development, policies and regulations in tourism development, and the capacity of resources provided by stakeholders in supporting tourism development (Sita, 2017). A score of 5 means very high, a score of 4 means high, a score of 3 means relatively high, two means less high, and one means low (Roslinda et al., 2012). The criteria of each score are presented in Table 1 and Table 2.

Table 1. Score and criteria of stakeholder role

\begin{tabular}{|c|c|c|}
\hline Aspect & Score & Criteria \\
\hline $\begin{array}{l}\text { K1 - stakeholder involvement (planning, } \\
\text { implementing, monitoring, and } \\
\text { evaluating the implementation of tourism } \\
\text { development) }\end{array}$ & $\begin{array}{l}5 \\
4 \\
3 \\
2 \\
1\end{array}$ & $\begin{array}{l}\text { Involved at all stages of development } \\
\text { involved in three stages of development } \\
\text { involved in two stages of development } \\
\text { involved in one stage of development } \\
\text { not involved in stage of development }\end{array}$ \\
\hline $\begin{array}{l}\text { K2 - benefits of tourism development for } \\
\text { stakeholders (including (source of } \\
\text { livelihood, PNBP income, create jobs, } \\
\text { open relationships, and encourage } \\
\text { regional development) }\end{array}$ & $\begin{array}{l}5 \\
4 \\
3 \\
2 \\
1\end{array}$ & $\begin{array}{l}\text { Get all the benefits of tourism development } \\
\text { Get three benefits } \\
\text { Get two benefits } \\
\text { Get one benefits } \\
\text { Do not get the benefit. }\end{array}$ \\
\hline $\begin{array}{l}\text { K3 - stakeholders authority of in } \\
\text { tourism development (protection and } \\
\text { security of tourism, construction of } \\
\text { infrastructure, licensing services, and } \\
\text { providing the information) }\end{array}$ & $\begin{array}{l}5 \\
4 \\
3 \\
2 \\
1\end{array}$ & $\begin{array}{l}\text { Involved at all stages of development } \\
\text { involved in three stages of development } \\
\text { involved in two stages of development } \\
\text { involved in one stage of development } \\
\text { not involved in all stages of tourism development }\end{array}$ \\
\hline $\begin{array}{l}\text { K4 - Stakeholder priority in tourism } \\
\text { development (included in work programs } \\
\text { or development plans, allocated } \\
\text { development budget, and involved in } \\
\text { previous development). }\end{array}$ & $\begin{array}{l}5 \\
4 \\
3 \\
2 \\
1\end{array}$ & $\begin{array}{l}\text { Focus on all sub-elements } \\
\text { Focus on three sub-elements } \\
\text { Focus on two sub-elements } \\
\text { Focus on one sub-element } \\
\text { Do not focus on all sub-elements. }\end{array}$ \\
\hline K5 - level of stakeholder dependence & $\begin{array}{l}5 \\
4 \\
3 \\
2 \\
1\end{array}$ & $\begin{array}{l}\text { tourism will not run without stakeholders } \\
\text { the role of stakeholders can still be replaced with other stakeholders } \\
\text { the presence of stakeholders has enough impact } \\
\text { stakeholders have little influence on tourism development } \\
\text { no effect on the existence of tourism }\end{array}$ \\
\hline
\end{tabular}

Table 2. Score and criteria of stakeholder influence level

\begin{tabular}{lcl}
\hline Aspect & Score & Criteria \\
\hline P1: The role and involvement of stakeholders & 5 & Play a role in all development aspects \\
(contribution in funds, land provision, human & 4 & Plays a role in three developments aspect \\
resources, providing information and knowledge) & 3 & Plays a role in two developments aspect \\
& 2 & Plays a role in one developments aspect \\
\hline P2: Stakeholder authority in tourism development & 5 & Has no role in the development aspect \\
(holding tourism development discussions, & 4 & Has authority in three elements \\
cooperation, promoting, and making and changing & 3 & Has authority in two elements \\
tourism development regulations and policies) & 2 & Has authority in one element \\
& 1 & Has no authority \\
\hline P3: Monitoring and evaluation in tourism & 5 & Giving all sanctions. \\
development (administrative sanctions, financial & 4 & Giving three sanctions \\
sanctions, moral sanctions, and legal sanctions) & 3 & Giving two sanctions \\
& 2 & Giving one sanction \\
\hline P4: Policies and regulations in tourism development & 5 & Has a role in designing all regulations/policies \\
(influential in the licensing process, preparation of & 4 & Has a role in designing three regulations/policies \\
planning documents, influential in business strategy, & 3 & Has a role in designing two regulations/policies \\
and drafting rules related to tourism development) & 2 & Has a role in designing one regulation/policies
\end{tabular}




\begin{tabular}{lcl}
\hline Aspect & Score & Criteria \\
\hline & 1 & Has no role in designing regulation/policies \\
\hline P5: The resources capacity provides by stakeholders & 5 & Has all resources \\
in supporting tourism development (sufficient budget & 4 & Has three resources \\
funds, human resources according to expertise, & 3 & Has two resources \\
providing infrastructure, detailed data, and & 2 & Has one resource \\
information, and statutory regulations) & 1 & Has no resources \\
\hline
\end{tabular}

Table 3 Scores of stakeholder interest and influence

\begin{tabular}{ccll}
\hline Score & Value & \multicolumn{1}{c}{ Criteria } & \multicolumn{1}{c}{ Explanation } \\
\hline \multicolumn{2}{l}{ Stakeholder Interest Level } & \\
\hline 5 & $21-25$ & Very high & Has a very high interest in tourism development \\
4 & $16-20$ & High & Has a high interest in tourism development \\
3 & $11-15$ & High enough & Has high enough interest in tourism development \\
2 & $6-10$ & Moderate & Has moderate interest in tourism development \\
1 & $0-5$ & Low & Has a low in tourism development \\
\hline Stakeholder Influence Level & \\
\hline 5 & $21-25$ & Very high & Very influential in tourism development \\
4 & $16-20$ & High & Influential in tourism development \\
3 & $11-15$ & High enough & Quite influential in tourism development \\
2 & $6-10$ & Not high enough & Less influential in tourism development \\
1 & $0-5$ & Low & It does not affect tourism development
\end{tabular}

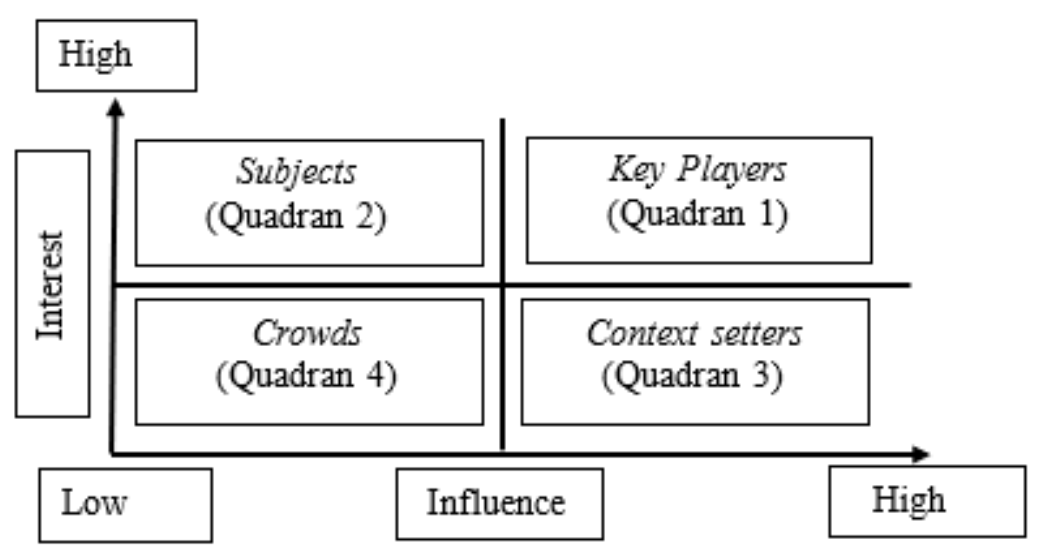

Figure 1 Stakeholder analysis matrix

Additional questions during field interviews were used as the discussion material. These additional questions include opinions on the development of adventure tourism, the current level of tourism development, the difficulties faced, the involvement of the surrounding community, the position and role of visitors, as well as potential stakeholders involved and their positions. The scoring values of these questions are added up, and measurements are made with a difference of five, presented in Table 3.

The next step is stakeholder mapping by adding up the scores of interests and influences of each stakeholder by forming coordinates with the position of the stakeholder roles presented in Figure 1. Quadrant 1 is occupied by stakeholders with a score of interest and influence $>12.5$. Quadrant 2 is occupied by stakeholders with an interest score of $>12.5$ and an influence of $<12.5$. Quadrant 3 is occupied by stakeholders with an interest score of $<12.5$ and an influence of $>12.5$. Quadrant 4 is occupied by stakeholders with an interest score of $<12.5$ and an influence of $<12.5$.

The stakeholder's classification results based on influence and interests are divided into four groups (Reed et al., 2009):

a. Keyplayers are stakeholders who have a high interest and influence in nature tourism activities.

b. Subjects are stakeholders who have high interest but low influence in nature tourism activities.

c. Contex setters are stakeholders who have strong influence but low importance in nature tourism activities.

d. Crowds are stakeholders who have low interest and influence in nature tourism activities.

3. Relations between stakeholders

Relationships between stakeholders were obtained through interviews with Perhutani, Kertaangsana Village 
Goverment, and Kompepar. The data were analyzed using descriptive analysis to identify the collaborative relationships between stakeholders that have not been carried out. Relationships between stakeholders are grouped into cooperative, coordination, and communication relationships (Santoso et al., 2015). The cooperation that has been carried out is in terms of coordination and division of labor for each stakeholder. However, some collaborations have not been maximally carried out, such as coordination between stakeholders; there is not yet one thought and understanding in tourism development

\section{RESULT AND DISCUSSION}

\section{Research Setting Condition}

The natural tourism area of Curug Bibijilan is one of the tourist destinations that is part of the Buniayu Cave Tourism Area and has an area of \pm 2.56 hectares. This tourist area is under the management of Perum Perhutani RPH Ciguha, Cikawung Forest Stakeholder Unit, KPH Sukabumi, Sukabumi Regency. Administratively, this tourist attraction is located in Lebak Nangka Village, Kertaangsana Village, Nyalindung District, Sukabumi Regency, or can be reached about $30 \mathrm{~km}$ (1.5 hours) from the center of Sukabumi City. Activities that are currently commonly carried out by visitors are picnicking, water tourism, and trekking. There are also special interest tours offered, namely Trekking, Climbing, and Flying Fox (1st Informant, 18 March 2021, Personal Interview Results).

Curug Bibijilan is a unique waterfall because it presents a stream of water flowing from limestone rocks that look like popping from the limestone with white splashes when viewed from a distance. The water in this waterfall is relatively clean, cold, and the discharge is moderate to heavy. Another landscape is seen from this area in the hills with primary forest ecosystems with dense vegetation cover. This waterfall is located in 3 forest ecosystems, namely primary, secondary, and plantation forests. Plantation forests are the most dominating ecosystem due to the allocation of Perhutani areas as production areas for pine resin (Pinus merkusii). Water is an essential resource in this area. Besides being designated as the primary resource in tourism activities, the hydrological services of the Bibijilan waterfall are also used to meet the daily needs of the surrounding community. The manager still maintains the traditional water pump system as one of the characteristics of the destination.

Based on observations, the types of biodiversity that can be found include tricolored squirrels (Callosciurus notatus), Javan treeshrew (Tupaia javanica), long-tailed macaque (Macaca fascicularis), and birds including sooty-headed bulbul (Pycnonotus aurigaster), barwinged prinia (Prinia familiaris), common kingfisher (Alcedo atthis), and black-naped oriole (Oriolus chinensis), oriental magpie-robin (Copsychus saularis), and swifts (Apodidae). According to the manager, other primates such as silvery gibbon (Hylobates moloch) and East Javan Langur (Trachypithecus auratus) can also be found at certain times. There are also several types of flora. The dominant family is the family Dipterocarpaceae (e.g., Shorea sp). This family has a uniqueness that can be seen from the ecological distribution, characteristics of trees, flowers, seeds, and benefits (Fajri, 2008). The other species found include puspa (Schima walichii), rasamala (Altingia excelsa), acacia (Acacia mangium), java olive tree (Sterculia foetida), Caqui (Manilkara kauki), big-leaf mahogany (Swietenia macrophylla), and small leaf mahogany (Swietenia mahagoni).

\section{Stakeholders Role in Tourism Development}

\section{a. Stakeholder Identification}

The results of stakeholder interviews in the development of natural tourism of Curug Bibijilan obtained ten stakeholders with their respective main tasks showing their current involvement so that some stakeholders who have not been involved still do not have main tasks. The identification results are classified into six groups: the central government, local government, local institutions, local tourism businesses, local communities, and visitors. The following explains the classification of stakeholders and the main tasks/business fields related to tourism development, presented in Table 3.

Stakeholders who are directly involved play a role and participate in developing the natural tourism of Curug Bibijilan. In contrast, stakeholders involved indirectly and have not been involved are stakeholders who do not participate in the development of natural tourism of Curug Bibijilan but have the potential to be involved in tourism activities (Race and Millar, 2008). The following presents the stakeholders' involvement in tourism development (Table 4). 
Table 3 Stakeholders involved in the natural-based tourism development of Curug Bibijilan.

\begin{tabular}{|c|c|c|}
\hline No & Stakeholder & Main tasks related to tourism development \\
\hline \multicolumn{3}{|c|}{ Central Government } \\
\hline 1 & $\begin{array}{l}\text { Perum Perhutani Forest Management Resort (RPH) } \\
\text { Ciguha, Division of Forest Management Unit (BKPH) } \\
\text { Cikawung, Forest Management Unit (KPH) Sukabumi }\end{array}$ & $\begin{array}{l}\text { Carry out planning, development, utilization, } \\
\text { maintenance, supervision, protection, security efforts } \\
\text { for ODTWA }\end{array}$ \\
\hline \multicolumn{3}{|c|}{ Local Government } \\
\hline 2 & Sukabumi Regency Tourism Office & $\begin{array}{l}\text { Involved in granting permits to open tourist areas in } \\
\text { Sukabumi Regency }\end{array}$ \\
\hline 3 & Sukabumi Regency Water Resources Utilization Service & No main tasks \\
\hline 4 & Sukabumi Regency Transportation Service & $\begin{array}{l}\text { Play a role in granting local transportation route } \\
\text { permits }\end{array}$ \\
\hline 5 & $\begin{array}{l}\text { Department of Industry and Energy and Mineral } \\
\text { Resources of Sukabumi Regency }\end{array}$ & No main tasks \\
\hline 6 & Kertaangsana Village Government & $\begin{array}{l}\text { Assisting Perhutani in licensing for regional } \\
\text { administration and coordinating in empowering local } \\
\text { communities }\end{array}$ \\
\hline \multicolumn{3}{|c|}{ Local Organization } \\
\hline & LMDH & $\begin{array}{l}\text { Assist in area management and coordinate in } \\
\text { community empowerment }\end{array}$ \\
\hline \multicolumn{3}{|c|}{ Local tourism industry } \\
\hline & Buni Ayu Traveling & $\begin{array}{l}\text { Assisting Perhutani in providing tour packages, } \\
\text { providing facilities and adventurous tour guides, and } \\
\text { promoting adventurous tourism activities. }\end{array}$ \\
\hline \multicolumn{3}{|c|}{ Local NGO } \\
\hline & Tourism Care Community Group (Kompepar) & $\begin{array}{l}\text { Cooperating with Perhutani in planning, developing, } \\
\text { utilizing, maintaining, monitoring, protecting, and } \\
\text { securing tourist destinations }\end{array}$ \\
\hline \multicolumn{3}{|c|}{ Tourist } \\
\hline 10 & Tourist & $\begin{array}{l}\text { Take on the role of a user and engage in a } \\
\text { promotion. }\end{array}$ \\
\hline
\end{tabular}

Table 4 the stakeholders' involvement in tourism development

\begin{tabular}{lll}
\hline \multicolumn{1}{c}{ Stakeholders directly involved } & $\begin{array}{l}\text { Stakeholders who are } \\
\text { not directly involved }\end{array}$ & Potential stakeholder \\
\hline $\begin{array}{l}\text { Perum Perhutani Forest Management Resort (RPH) } \\
\text { Ciguha, Division of Forest Management Unit (BKPH) }\end{array}$ & Buni Ayu Traveling & $\begin{array}{l}\text { Sukabumi Regency Water } \\
\text { Resources Utilization Service }\end{array}$ \\
$\begin{array}{l}\text { Cikawung, Forest Management Unit (KPH) Sukabumi } \\
\text { Kertaangsana Village Government }\end{array}$ & LMDH & $\begin{array}{l}\text { Department of Industry and } \\
\text { Energy and Mineral Resources } \\
\text { of Sukabumi Regency }\end{array}$ \\
Tourism Care Community Group (Kompepar) & $\begin{array}{l}\text { Sukabumi Regency } \\
\text { Tourism Office } \\
\text { Sukabumi Regency } \\
\text { Transportation Service } \\
\text { Visitors }\end{array}$ & \\
\hline
\end{tabular}

Table 4 shows that the natural tourism development of Curug Bibijilan involves several stakeholders. The form of stakeholder involvement in tourism development is the contribution of funding, land provision, human resources (HR), and the provision of information and knowledge facilities. Participation of stakeholders involved in tourism development by cooperating and coordinating between stakeholders, but not all stakeholders are involved. Some stakeholders have not been involved and are expected to be involved. Based on the results of the interviews, collaboration with potential stakeholders should immediately be held.

\section{b. Mapping and Stakeholder Roles}

The results of the assessment of the level of stakeholder interest in the development of natural tourism of Curug Bibijilan are based on five questions/main elements and a score that has been prepared previously. The magnitude of the interest is assessed based on the involvement of stakeholders in tourism development, the benefits of tourism 
development for stakeholders, the authority of stakeholders in tourism development, the priority scale of stakeholders in tourism development, and the level of dependence of stakeholders in tourism development (Reed et al., 2009). Additional questions during field interviews were used as the discussion material. The scoring compilation results of the stakeholder interest level in tourism development are stated in Table 5.

Perum Perhutani RPH Ciguha, Kertaangsana Village, and Kompepar are involved in planning, implementing, monitoring, and evaluating the implementation of tourism development. Buni Ayu Traveling (BAT) and the Forest Village Community Institution (LMDH) are only involved in implementing tourism development. The Tourism Office only plays a role in licensing. Visitors are only users and influence the promotion. The local government stakeholders such as the Department of Transportation, the Department of Water, and the Department of Energy and Mineral Resources are not directly involved in tourism development. Still, they can become collaborative partners in the development of natural tourism in Curug Bibijilan. Visitors have an interest in evaluating tourism development.

Perhutani gets all the benefits of tourism development, namely the benefits of the livelihood sources availability, PNBP income, creating jobs, opening relationships, and encouraging regional development. Kertaangsana and Kompepar villages benefit from obtaining livelihood sources, creating jobs, opening relationships, and promoting regional development. LMDH and BAT only benefit from livelihood sources. Local government stakeholders and visitors have not received any benefit from developing the natural tourism of Curug Bibijilan.

Perhutani has all stakeholder authorities in tourism development, namely the power to protect and secure tourism, develop facilities and infrastructure, provide licensing services, and provide information. Kertaangsana Village and the Tourism Office are authorized to protect and secure tourism, provide licensing services, and provide information. Kompepar is authorized to provide protection, build facilities and infrastructure, and provide information. BAT is authorized to develop facilities and infrastructure, provide licensing services, and provide information. LMDH, the Department of Transportation, the Department of Water, the Department of Energy and Mineral Resources, and visitors do not have the authority to develop nature-based tourism in Curug Bibijilan.

The priority scale levels of Perhutani, Kertaangsana Village, and Kompepar are very priority because they focus on all sub-elements, namely being included in the work program, included in the plan, allocating the development budget, and being involved in previous developments. The level of LMDH's priority scale is less priority; it only focuses on allocating development budgets and prior developments. The priority level of BAT is less priority. That is, it only focuses on tourism development plans and is involved in earlier development. The level of priority scale of the Department of Transportation, the Department of Tourism, the Department of Water, the Department of Energy and Mineral Resources, and visitors are not a priority because they do not focus on the four subelements.

Table 5 The level of stakeholder interest in tourism development.

\begin{tabular}{|c|c|c|c|c|c|c|c|}
\hline \multirow{2}{*}{ No } & \multirow{2}{*}{ Stakeholder } & \multicolumn{5}{|c|}{ Interests } & \multirow{2}{*}{ Total } \\
\hline & & K1 & $\mathbf{K 2}$ & K3 & K4 & K5 & \\
\hline 1 & Perum Perhutani RPH Ciguha & 5 & 5 & 5 & 5 & 5 & 25 \\
\hline 2 & Kertaangsana Village & 5 & 4 & 4 & 5 & 5 & 23 \\
\hline 3 & Tourism Care Community Group & 5 & 4 & 4 & 5 & 4 & 22 \\
\hline 4 & Forest Village Community Institution & 2 & 2 & 1 & 3 & 2 & 10 \\
\hline 5 & Sukabumi Regency Transportation Service & 1 & 1 & 1 & 1 & 1 & 5 \\
\hline 6 & Sukabumi Regency Tourism Office & 1 & 1 & 4 & 1 & 5 & 12 \\
\hline 7 & Sukabumi Regency Water Resources Utilization Service & 1 & 1 & 1 & 1 & 1 & 5 \\
\hline 8 & $\begin{array}{l}\text { Department of Industry and Energy and Mineral Resources } \\
\text { of Sukabumi Regency }\end{array}$ & 1 & 1 & 1 & 1 & 1 & 5 \\
\hline 9 & Buni Ayu Traveling & 2 & 2 & 4 & 3 & 4 & 15 \\
\hline 10 & Visitors & 2 & 1 & 1 & 1 & 1 & 6 \\
\hline
\end{tabular}

Description: K1: stakeholder involvement (planning, implementing, monitoring, and evaluating the implementation of tourism development); K2: benefits of tourism development for stakeholders (including (source of livelihood, PNBP income, create jobs, open relationships, and encourage regional development); K3: stakeholders authority of in tourism development (protection and security of tourism, construction of infrastructure, licensing services, and providing the information); K4: Stakeholder priority in tourism development (included in work programs or development plans, allocated development budget, and involved in previous development); K5 - level of stakeholder dependence. Skor: 5: Very high; 4: High; 3: Fairly high; 2: Not high enough; 1: Low 
The dependence level of Perhutani, Kertaangsana Village, and the Tourism Office on tourism development are very high because the natural tourism of Curug Bibijilan cannot run without the relevant stakeholders. The dependence level of Kompepar and BAT on tourism development is high. The dependence level of LMDH on tourism development is low because its presence is quite influential in tourism development. After all, the presence of influence stakeholders is very high, but its role can still be replaced with other stakeholders. The level of dependence of the Department of Transportation, the Department of Energy and Mineral Resources, the Department of Water, and visitors on tourism development is very low because they are not affected by the existence of nature-based tourism in the Bibijilan waterfall. Table 6 presents the scoring result compilation of the stakeholder influence level in tourism development.

Perhutani has a role in all sub-elements of tourism development, contributing to funding, providing land, contributing human resources, and contributing to information and knowledge. Kompepar has a role in funding contributions, HR contributions, and contributing to information and expertise in tourism development. BAT has a role in providing land, information, and knowledge. Kertaangsana Village and the Tourism Office only play a role in providing information and knowledge. LMDH only plays a role in providing human resources. The Department of
Transportation, the Department of Water, the Department of Energy and Mineral Resources, and visitors do not play a role in tourism development.

Perhutani conducts all interactions related to tourism development, namely holding discussions, holding collaborations, promotions, and making/changing tourism development regulations and policies. Kompepar is authorized to have discussions and promote tourism development. BAT is authorized to conduct cooperation and promotion of tourism development. Kertaangsana Village and LMDH are only authorized to promote tourism development. Visitors play a role in the promotion of tourism development. The Department of Transportation, the Department of Tourism, the Department of Water, and the Department of Energy and Mineral Resources do not carry out all the interactions of the sub-elements so that they are not authorized to interact with tourism development.

Perhutani conducts monitoring and evaluation by providing all sanctions in tourism development, including providing administrative, financial, moral, and legal sanctions. The Tourism Office offers administrative and moral sanctions. Kertaangsana Village only gave administrative sanctions, while Kompepar only gave moral sanctions. Stakeholders who do not provide sanctions include LMDH, the Department of Transportation, the Department of Water, the Department of Energy and Mineral Resources, BAT, and visitors.

Table 6 Level of stakeholder influence in tourism development.

\begin{tabular}{|c|c|c|c|c|c|c|c|}
\hline \multirow{2}{*}{ No } & \multirow{2}{*}{ Stakeholder } & \multicolumn{5}{|c|}{ Influence } & \multirow{2}{*}{ Total } \\
\hline & & P1 & $\mathbf{P 2}$ & P3 & P4 & P5 & \\
\hline 1 & Perum Perhutani RPH Ciguha & 5 & 5 & 5 & 4 & 3 & 22 \\
\hline 2 & Kertaangsana Village & 2 & 2 & 2 & 4 & 2 & 12 \\
\hline 3 & Tourism Care Community Group & 4 & 3 & 2 & 4 & 1 & 14 \\
\hline 4 & Forest Village Community Institution & 2 & 2 & 1 & 3 & 1 & 8 \\
\hline 5 & Sukabumi Regency Transportation Service & 1 & 1 & 1 & 1 & 1 & 5 \\
\hline 6 & Sukabumi Regency Tourism Office & 2 & 1 & 3 & 2 & 2 & 10 \\
\hline 7 & Sukabumi Regency Water Elementary School Utilization Service & 1 & 1 & 1 & 1 & 1 & 5 \\
\hline 8 & $\begin{array}{l}\text { Department of Industry and Energy and Mineral Resources of Sukabumi } \\
\text { Regency }\end{array}$ & 1 & 1 & 1 & 1 & 1 & 5 \\
\hline 9 & Buni Ayu Traveling & 3 & 3 & 1 & 2 & 4 & 13 \\
\hline 10 & Tourist & 1 & 2 & 1 & 1 & 1 & 6 \\
\hline
\end{tabular}

Description: P1: The role and involvement of stakeholders (contribution in funds, land provision, human resources, providing information and knowledge); P2: Stakeholder authority in tourism development (holding tourism development discussions, cooperation, promoting, and making and changing tourism development regulations and policies); P3: Monitoring and evaluation in tourism development (administrative sanctions, financial sanctions, moral sanctions, and legal sanctions); P4: Policies and regulations in tourism development (influential in the licensing process, preparation of planning documents, influential in business strategy, and drafting rules related to tourism development); P5: The resources capacity provides by stakeholders in supporting tourism development (sufficient budget funds, human resources according to expertise, providing infrastructure, detailed data, and information, and statutory regulations). Skor: 5: Very high; 4: High; 3: Fairly high; 2: Not high enough; 1: Low. 
Policies and regulations made by Perhutani, Desa Kertaangsana, and Kompepar all affect tourism development, namely influencing the licensing process, drafting planning documents, preparing business strategies, and regulations relating to tourism development. The policies and regulations made by LMDH affect the licensing process and the preparation of rules on tourism development. The policies and regulations of the Tourism Office only affect the licensing process, while the policies and regulations made by BAT only affect the preparation of tourism development regulations. Stakeholders whose policies do not affect the development of natural tourism at Curug Bibijilan are the Department of Transportation, the Department of Energy and Mineral Resources, the Department of Water, and visitors.

The resource capacity provided by the stakeholders varies. The resource capacity provided by BAT includes human resources according to expertise, facilities, and infrastructure, as well as accurate data and information related to the nature-based tourism of Curug Bibijilan. Perhutani provides facilities and infrastructure, as well as laws and regulations that support tourism development. The resource capacity provided by Kertaangsana Village and the Tourism Office is only statutory regulations that support tourism development. Stakeholders who do not provide resources following their capacities are Kompepar, LMDH, Transportation Service, ESDM Service, Water Service, and visitors.

The matrix shows the position and role of stakeholders in the development of natural tourism of Curug Bibijilan. The stakeholders in the key player's group are Perhutani, Kompepar, and BAT. The stakeholders in the contex setter (Quadrants III) is Kertaangsana Village. There are no identified stakeholders in quadrants II as the subject of the natural tourism development of Curug Bibijalan. Stakeholders identified in quadrant IV (crowds) include LMDH, the Tourism Office, the Transportation Service, the Water Service, and the Energy and Mineral Resources Office. Stakeholders in this quadrant can work together to develop the natural tourism of Curug Bibijilan, thus requiring more attention from other stakeholder groups, but not in high priority because the capacity of stakeholder crowds is very low. Stakeholders in the crowd's group do not require intensive involvement in achieving goals. Still, monitoring and evaluation need to be carried out periodically to determine the extent to which activities have developed their interests (Muzani, 2014).

\section{c. Relations between stakeholders}

The involvement of each stakeholder in tourism development varies depending on the tasks and roles they have. The relationship between stakeholders is a form of cooperation, communication, and coordination in developing the natural tourism of Curug Bibijilan. More cooperation and coordination are found in the field. The relationship between stakeholders shows that it is necessary to form an agreement and understanding regarding the development of natural tourism in Bibijilan Waterfall. This is similar to Widiyanti's research (2016) regarding the governance of ecotourism development in the Ijen Crater Tourism Park, East Java Province, which explains that cooperation and coordination are the most common stakeholder relationships found in the field. Cooperation is a joint effort between individuals or groups to achieve one or more shared goals (Bungin, 2008).

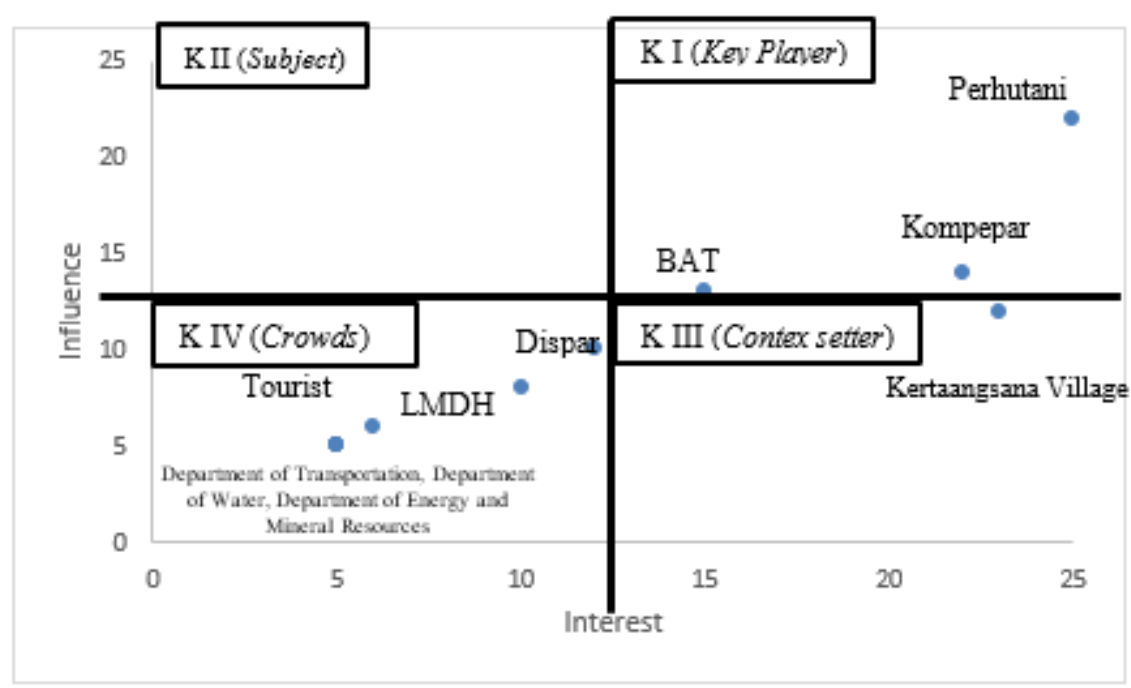

Figure 2 Stakeholder Matrix 
The forms of collaboration between stakeholders that have been carried out include collaboration between Perum Perhutani and the Kertaangsana Village Government in community involvement in Curug Bibijilan. The Village Government assists in the coordination of community data. The establishment of Kompepar and the involvement of LMDH also began with the cooperation between the village and Perhutani. Perum Perhutani, Kompepar, and BAT cooperate in terms of promotion and provision of tourism services. Perhutani and Kompepar are responsible for the area and resources, while BAT is responsible for services. Cooperation between Kertaangsana Village and the Department of Transportation for licensing local transportation routes to access roads to the area. Communication relationships between stakeholders occur in almost every development activity. However, communication is mainly aimed at activities involving the community between Perhutani, Villages, and Kompepar. Likewise, more coordination is carried out by the three stakeholders. An example is a coordination with the community regarding the opening and closing of tours at certain times.

In addition to those described above, there are still several stakeholders who do not have a relationship. This is because many potential stakeholders do not have the main task of developing adventure tourism in Curug Bibijilan. Some of the main functions that are expected from each stakeholder who is not directly involved and has not been involved include the following:

a. Buni Ayu Traveling (BAT)

BAT, which is currently only involved in implementing tourism development, is also expected to be involved in its planning and evaluation. BAT is believed to have professional human resources in adventure tourism, such as having expertise in outdoor sports activities, having certifications, and complete facilities. BAT is also expected to encourage strategies in the promotion and provision of area information for visitors. The presence of BAT can also encourage professionals from the community to become certified guides with targeted training. An evaluation from BAT is also needed so that other stakeholders can get input to improve the previous management. Thus, in addition to the benefits of livelihood sources, BAT can also benefit from employment opportunities for the community. The involvement of BAT as a stakeholder currently occurs indirectly. Based on the interview results, Perhutani expects an official MoU between Perhutani and BAT soon. So that in the future, BAT can be included in the work program and receive a budget allocation as a stakeholder with high priority because current conditions show that BAT has a high influence and cannot be replaced by other agents/parties.

b. Forest Village Community Institution (LMDH)

Currently, the LMDH involvement as an implementer is starting to decrease, even though LMDH has been involved from the start. As a form of community empowerment, LMDH is expected to be involved starting from tourism planning. LMDH can be directed by Perhutani as part of forest ecosystem management planning around the adventure tourism area so that it remains sustainable so that it also has the authority to protect and secure. This is because LMDH has been involved in previous developments, but the existence of LMDH, which is getting less attention, makes its influence and importance currently still low. The presence of connections between community members in LMDH is expected to open relationships and encourage regional development in this village.

c. Sukabumi Regency Tourism Office

The full involvement of the Tourism Office is also highly expected. The Human Resources they have are expected to encourage the quality of tourism management in Curug Bibijilan. Currently, Dispar has not had any engagements. The tourism office is expected to be involved in all sub-elements from planning, implementing, monitoring, to evaluation. The existence of a tourism office is also expected to open relations, especially with investors. Because one of the current obstacles is the availability of development capital. The Tourism Office is also an agency with great potential to promote the area and provide information facilities.

d. Sukabumi Regency Transportation Service

The stakeholder's involvement is expected to be in constructing facilities and infrastructure, especially in transportation accommodation. Accessibility is one factor that still needs to be considered because even though it has good road conditions, the amount of transportation available is still small.

e. Visitors

Some of the activities that have involved visitors are during a ticket price survey conducted by Perhutani. Although not through a precise research instrument such as Willingness To Pay, this is a good step taken by Perhutani. The involvement of visitors is crucial because the expectations of adventure travelers are a vital part of setting the background for the experience and the assessment of services (Buckley et al., 2014). It is critical for adventure tourism providers to understand these ideas and motivations and their interrelationships, to prepare adequate experiences and products (Ponte et al., 2021). Currently, the role of visitors has indirectly influenced the promotion of the area. Thus the expected role of visitors is in developing tourism business strategies.

\section{f. Sukabumi Regency Water Service}

Sukabumi is one of the areas that sell water as the selling value. Currently, there are no professional experts in managing water resources in this area, such as the regulation of carrying capacity, water discharge and quality regulation, and other forms of water management as the main selling point of the area. The Department of Waters is needed as a provider of human resources according to expertise so that it helps in providing detailed data and information to prepare planning documents. 
g. Department of Industry and Energy and Mineral Resources of Sukabumi Regency

The same applies to the involvement of the Department of Waters. The involvement of the Department of Energy and Mineral Resources is also needed as a provider of HR according to expertise to assist in providing detailed data and information to prepare planning documents related to geology in the area around the karst area.

\section{CONCLUSION}

Ten stakeholders are involved and potentially involved in adventure tourism development at Curug Bibijilan, which are has a role as Key Players, Contex Setters, and Crowds based on their influence and interests. The stakeholders in the key player's (strong influence and high importance) group were Perhutani, Kompepar, and BAT. The stakeholders in the contex setter (Quadrants III - strong influence but low interest) was Kertaangsana Village. There were no identified stakeholders in quadrants II as the subject of the natural tourism development of Curug Bibijalan. Stakeholders identified in quadrant IV (crowds - low influence and low interest) include LMDH, the Tourism Office, the Transportation Service, the Water Service, and the Energy and Mineral Resources Office.

The relationship between stakeholders in the form of communication, coordination, and cooperation has not been written in the document and only carried out in the field. Stakeholders included in the Key Players classification have many relationships between stakeholders and a significant role in developing adventure tourism at Curug Bibijilan. The involvement of potential stakeholders is expected to support adventure tourism activities in this area based on the components of interest and influence from the results of the latest stakeholder analysis.

\section{REFERENCES}

Amalyah R, Hamid D, Hakim L. 2016. Peran stakeholder pariwisata dalam pengembangan Pulau Samalona Sebagai Destinasi Wisata Bahari. JAB. 37(1): 158163.

Buckley R, McDonald R, Duan L, Sun L, Chen LX. 2014. Chinese model for mass adventure tourism. Tourism Management. 44: 5-13.

Buckley R. 2006. Adventure tourism research: a Guide to the literature. Tourism Recreation Research. 31(2): 75-83.

Bungin B. 2008. Sosiologi Komunikasi: Teori Paradigma dan Diskursus Teknologi Komunikasi di Masyarakat. Jakarta: Kencana.

Cheng M, Edwards D, Darcy S, Redfern K. 2018. A Trimethod approach to a review of adventure tourism literature: Bibliometric analysis, content analysis, and a quantitative systematic literature review. Journal of Hospitality and Tourism Research. 42(6): 997-1020.

Fairuza M. 2017. Kolaborasi antar stakeholder dalam pembangunan inklusif pada sektor pariwisata. Kebijakan dan Manajemen Publik. 5(3): 1-13.

Fajri M. 2008. Pengenalan umum Dipterocarpaceae, kelompok jenis bernilai ekonomi tinggi. Info Teknis Dipterokarpa. 2(1): 19-21.

Hanafiah MH, Azman I, Jamaluddin MR, Aminuddin N. 2016. Responsible tourism practices and quality of life: Perspective of Langkawi Island communities. Procedia - Social and Behavioral Sciences. 222: 406413.

Idrus M. 2009. Metode Penelitian IlmuIlmu Sosial (Pendekatan Kuantitatif dan Kualitatif). Yogyakarta: UII Press.

Kurniawan F, Adrianto L, Bengen DG, Prasetyo LB. 2016. Vulnerability assessment of small islands to tourism: The case of the Marine Tourism Park of the Gili Matra Islands, Indonesia. Global Ecology and Conservation. 6(2016): 308-326.

Ladkin A, Bertramini AM. 2002. Perencanaan pariwisata kolaboratif: Studi Kasus Cusco, Peru. Isu Tekini dalam Pariwisata. 5(2): 71-93.

Mahfud MAZ, Haryono BS, Anggraeni NLV. 2015. Peran dan koordinasi stakeholder dalam pengembangan kawasan minapolitan di Kecamatan Nglegok, Kabupaten Blitar. JAP. 3(12): 2070-2076.

Minnaert L. 2020. Stakeholder stories: Exploring social tourism networks. Annals of Tourism Research. 83(2020): 102979.

Muzani. 2014. Strategi peningkatan peran stakeholder dalam pengelolaan mangrove di Kabupaten Tangeran. Jurnal Spatial Wahana Komunikasi dan Informasi Geografi. 12(2): 21-27.

Pendit NS. 2006. Ilmu Pariwisata: Sebuah Pengantar Perdana. Jakarta: PT. Pradnya Paramita.

Ponte J, Couto G, Sousa A, Pimentel P, Oliveia A. 2021. Idealizing adventure tourism experiences: Tourism self-assessment and expectations. Journal of Outdoor Recreation and Ecotourism. 35(2021):100379.

Race D, Millar J. 2008. Social and community dimension to ACIAR Research. ACIAR Training Manual. 4:33.

Rantala O, Rokenes J. 2016. Is adventure tourism a coherent concept? A review of research approaches on adventure tourism. Annals of Leisure Research. 21 (5): 539-552.

Reed SM, Graves A, Dandy N, Posthumus H, Huback K, Morris J, Quin CH, Stringer LC. 2009. Who's is and my why? A typology of stakeholders analysis methods for natural resource management. Journal of Environment Management. 1-17.

Roslinda E, Darusman D, Suharjito D, Nurrochmat DR 2012. Analisis pemangku kepentingan dalam pengelolaan Taman Nasional Danau Sentarum 
kabupaten Kapuas Hulu, Kalimantan Barat. Jurnal Manajemen Hutan Tropika. 18(2): 78-85

Santoso H, Muntasib EKSH, Kantodihardjo H, Soekmadi R. 2015. Peranan dan kebutuhan pemangku kepentingan dalam tata kelola pariwisata di Taman Nasional Bunaken Sulawesi Utara. Jurnal Penelitian Sosial dan Ekonomi Kehutanan. 12(3): 197-211.

Sita PV. 2017. Dampak Ekonomi dan analisis kelembagaan Wisata Alam Laut Pasir Taman Nasional Bromo Tengger Semeru [skripsi]. Bogor: Institut Pertanian Bogor.

Tarigan WP, Komsary KC, Maulana Y. 2018. Produk pariwisata off-road Sukabumi Jawa Barat. Jurnal Hospitality dan Kepariwisataan. 4(1): 1-69.
Trihayuningtyas E, Rahtomo W, Darmawan H. 2018. Rencana tata kelola destinasi pariwisata Kawasan Pulau Camba-Cambang dan sekitarnya di Kabupaten Pangkajene dan Kepulauan. Jurnal Manajemen Resort dan Leisure. 15(1).

Weber. 2001. Outdoor adventure tourism. Annals of Tourism Research. 18(2): 360-377.

Widiyanti H. 2016. Strategi tata kelola pengembangan ekowisata di taman wisata alam Kawah Ijen Provinsi Jawa Timur [Tesis]. Bogor: Institut Pertanian Bogor.

Widodo. 2017. Metodologi Penelitian Populer dan Praktis. Jakrta: PT Raja Grafindo Persada. 